\title{
上顎洞根治手術における術中出血量の検討
}

\author{
柬理十三雄・吉川隆淑・佐野公人 \\ 西村恒一*. 加藤譲治**. 又 賀 泉**
}

\section{A study of estimated blood loss during maxillary sinus radical operation}

\author{
Tomio Kanri - Takatoshi Yoshikawa - Kimito SANo \\ Koichi Nishimura* · Joji Kato** - Izumi MatagA**
}

\begin{abstract}
We have examined the estimated blood loss of 200 patients had a maxillary sinus radical operation in the central operating room of The Nippon Dental University, School of Dentistry at Niigata Dental Hospital from February 1979 to May 1987.

The subjects included 106 males and 94 females, ranged from class 1 to class 2, according to ASA classification. Their ages ranged from 1.5 to 73 years and the average age was 42.1 \pm 12.6 years. Their body weights ranged from 7.9 to $92.8 \mathrm{~kg}$ and the average body weight was $56.4 \pm 10.0 \mathrm{~kg}$.

Referring to the methods of anesthesia, nitrous oxide-oxygen-halothane was applied to 94 cases, nitrous oxide-oxygen-enflurane to 60 cases, and neurolept anesthesia to 46 cases, 181 cases in which vasoconstrictors were used during operation.

A correlationship was observed between body weight and estimated blood loss.

The estimted blood loss would increase with an increase in the operative time, a correlationship was observed between these factors.

Cases of odontogenic maxillary sinusitis had larger estimated blood loss than those of postoperative maxillary cyst, with a statistically significant difference observed.

There were no statistically significant differences observed in relation to methods of anesthesia, kinds of vasoconstrictors used, and whether or not a vasoconstrictor was used.

The least estimated blood loss was shown by the group having an average systolic blood pressure (SBP) of $100 \mathrm{mmHg}$ or lower, resulting in statistically significant differences from the respective groups having 101 to $120 \mathrm{mmHg}$ and $121 \mathrm{mmHg}$ or higher.
\end{abstract}

Key words: odontogenic maxillary sinusitis (速性上顎洞炎), postoperative maxillary cyst (術 後性上顎胞), estimated blood loss (出血量)

日本幽科大学新潟隧学部粎科麻酔学教室 (主任：真理十三雄教授)

* 日本荬科大学新潟迷学部口腔外科学教室第 1 諈座 （主任：西村恒一教授）

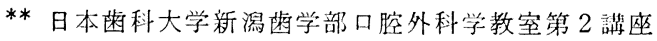
（主任：加藤譲治教授） Department of Anesthesiology, School of Dentistry at Niigata, The Nippon Dental University (Chief: Prof. Tomio Kanri)
* Department of Oral and Maxillofacial Surgery I, School of Dentistry at Niigata, The Nippon Dental University (Chief: Prof. Koichi Nishimura)

** Department of Oral and Maxillofacial Surgery II, School of Dentistry at Niigata, The Nippon Dental University (Chief: Prof. Joji Kato) 受付日：平成元年 3 月 


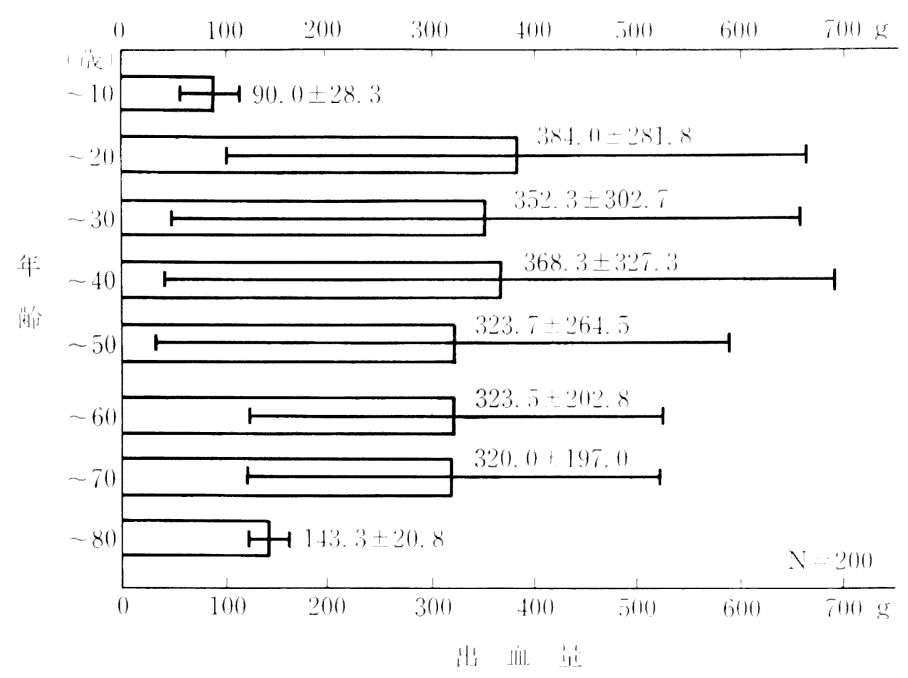

図 1 年棵别出血量

\section{緒}

言

靧顔面領域を対象とした口腔外科の手術では, 術野が 脈管系に富も組織であり，全身管理といら钼点からも術 中の出血量に留意しなければならない

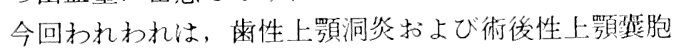
の診断のもとに, 全身麻酔下に上顈洞根治手術を受けた 200 例について, 術中の出血量を患者の年龄 - 体重, 手 術時間, 診断名, 麻酔法, 術中の収縮期血圧 (以下 SBP) などの観点から検索した結果, 若干の知見が得られたの で考察を加え報告する。

\section{対}

\section{象}

対象は昭和 54 年 2 月から昭和 62 年 5 月までの期間に, 日本歯科大学新舅歯学部附属病院中央手術室にて上頢洞 根治手術を受けた男性 106 例，女性94例である。

対象の年龄は, $1.5 \sim 73$ 藏, 平均 $42.1 \pm 12.6$ 歳であっ た。体重は, $7.9 \sim 92.8 \mathrm{~kg}$, 平均 $56.4 \pm 10.0 \mathrm{~kg}$ であっ た.

手術時間は20〜170分，平均 77.0 分であった。

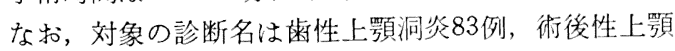
裡胞 117 例であった。

麻酔法は, 笑気・酸素・八口セン (以下 GOF) 94例, 笑気・酸素・エンフルレン (以下 GOE ) 60 例, neurolept anesthesia (以下 NLA) 46例であった.

また, 術中に血管収縮薬添加局所麻酔液を使用した症 例は181例あり，その内訳は，0.03 I.U.フェリプレシン 添加 $3 \%$ プリロイン 105 例, 1/20万エピネフリン添加
$0.5 \%$ リドカイン76例であった。

執刀開始から手術終了までの SBP の平均は最低倬86.1 $\mathrm{mmHg}$, 最高值 $149.6 \mathrm{mmHg}$ であった。

\section{方法}

出血量の測定は, ルナーハックRおよび Medi-Vack を用いた吸引法、ガーゼを用いた重量法にて経時的に行 (1,2)，最終的に綾量に $10 \%$ を加算し，クラムにて算出 した。

得られた結果はWelch の平均値の差の梚定法に準じ， Canon 社製スモールコンピューター BX-1Rにて統計 学的に処理した。

\section{結果}

今回検索を行った 200 例の出血量は, 最少 $30 \mathrm{~g}$, 最多 $1,360 \mathrm{~g}$, 平均 $370.4 \mathrm{~g}$ であった。

年柃別に出血量を比較してみると，10㓕以下の群では $90.0 \pm 28.3 \mathrm{~g} ， 11 \sim 20$ 歳の群では $384.0 \pm 281.8 \mathrm{~g}, 21$ 一 30歳の群では $352.3 \pm 302.7 \mathrm{~g} ， 31$ 40歳の群では 368.3 $\pm 327.3 \mathrm{~g}, 41 \sim 50$ 藏の群では $323.7 \pm 264.5 \mathrm{~g}, 51 \sim 60$ 歳の群では $323.5 \pm 202.8 \mathrm{~g} ， 61 〜 70$ 歳の群では 320.0土 $197.0 \mathrm{~g} ， 71$ 歳以上の群では143.3土20.8 g であった（図

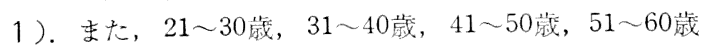
の各群の出血量の間に統計学的有意差は認められなかっ た。なお，20歳以下，61歳以上については対象の数が少 ないため統計学的唡索は行わなかった。

体重別について出血量を比較してみると，20 kg 以下 の群では90.0土28.3 g, 21〜 40 kg の群では328.0土174.0 


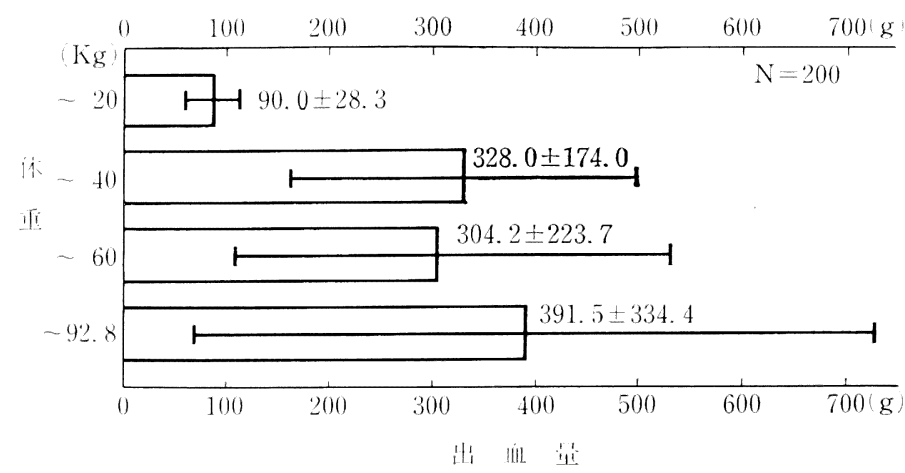

図 2 体重別出血量

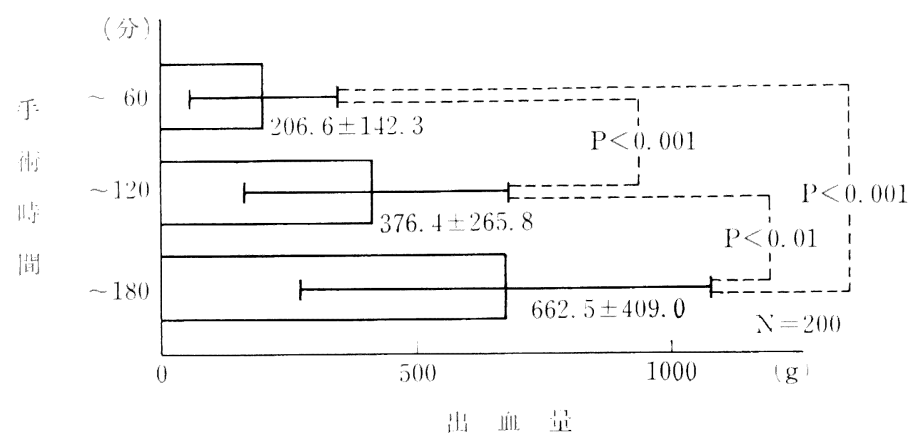

図 3 手術時間別出血量

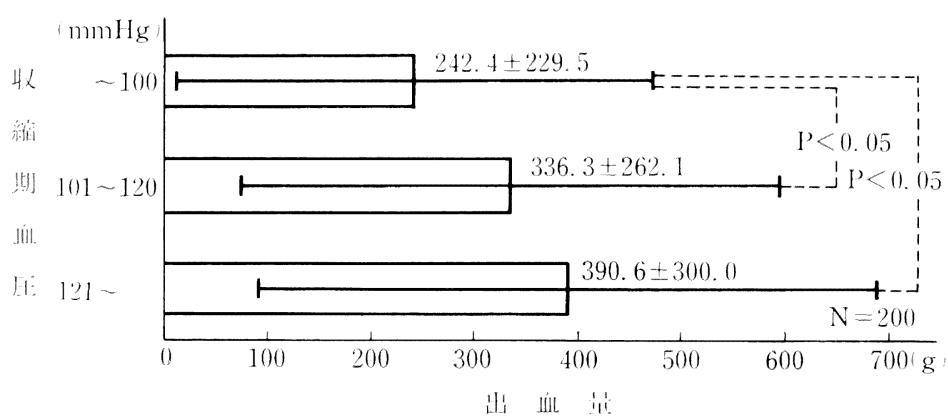

図 4 収縮期血圧別出血量

$\mathrm{g}, 41 \sim 60 \mathrm{~kg}$ の群では $304.2 \pm 223.7 \mathrm{~g}, 61 \mathrm{~kg}$ 以上の 群では $391.5 \pm 334.4 \mathrm{~g}$ であり，21〜 40kg, 41〜60 kg, $61 \mathrm{~kg}$ 以上の各群間に統計学的有意差は認められなかっ た（図 2)。な拈，20 kg 以下の群については対象の数が 少ないため統計学的検索は行わなかった。

手術時間別について出血量を比較してみると，60分以 下の群では206.6土142.3 g，61～120分の群では376.4土 $265.8 \mathrm{~g}, 121$ 分以上の群では662.5土409.0 g と, 手術時 間が長くなるほど，出血量が増加する傾向にあり，3 群
間に統計学的有意差が認められた（図3）。

診断別にみた出血量は, 歯性上顎洞炎 $384.6 \pm 291.5 \mathrm{~g}$,

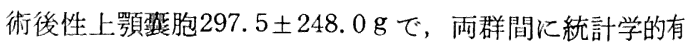
意差が認められた。

麻酔法別にみた出血量は, GOF 群 $370.4 \pm 290.9 \mathrm{~g}$, GOE 群 $290.9 \pm 256.3 \mathrm{~g}, \mathrm{NLA}$ 群 $336.7 \pm 275.5 \mathrm{~g}$ で3 群間に統計学的有意差は認められなかった。

なお，血管収縮薬を 181 例に使用しており，使用群の 出血量は $326.7 \pm 271.9 \mathrm{~g}$, 非使用群の出血量は $400.0 \pm$ 


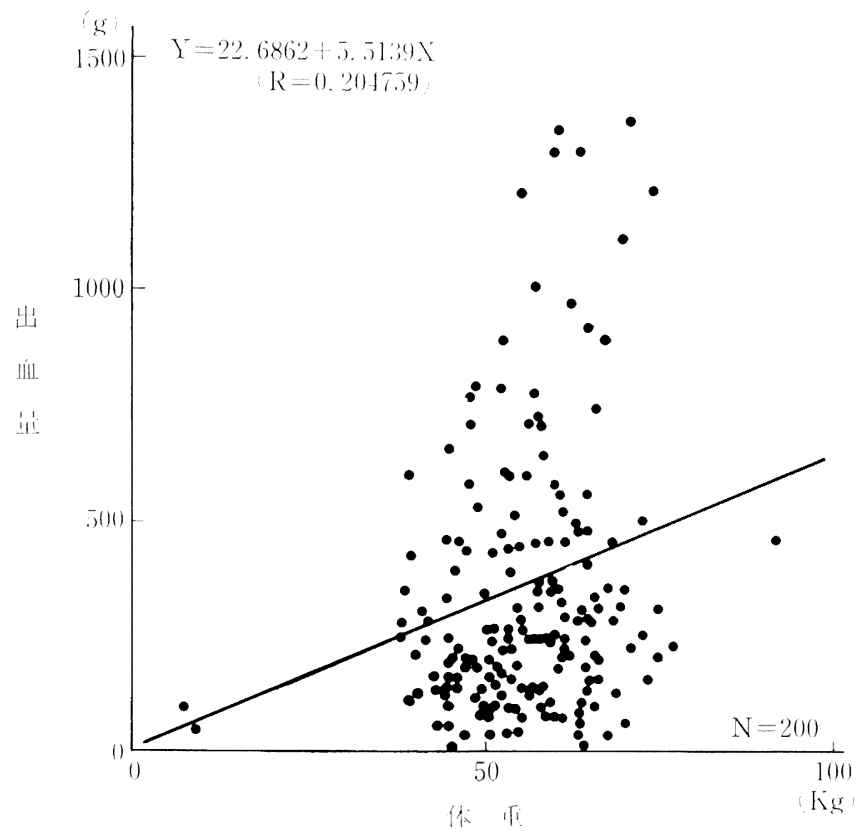

図 5 出血量と体重の相関関係

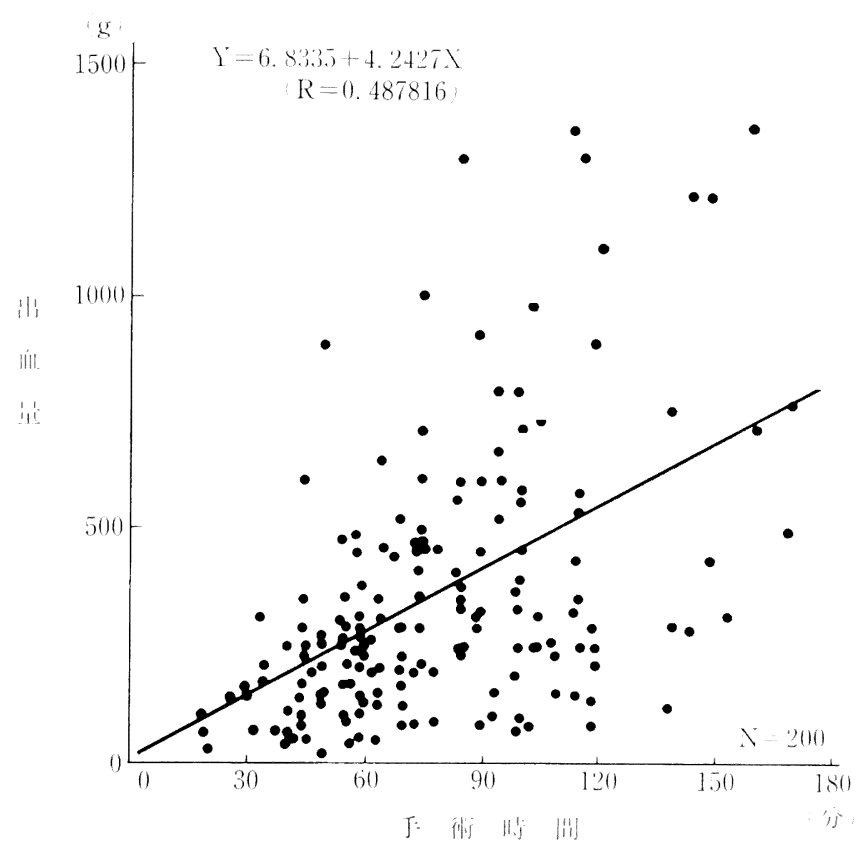

図 6 出血量と手術時間の相関関係

$244.5 \mathrm{~g}$ で両群間に統計学的有意差は認められなかった。 また，血管収縮薬の違いによる出血量の変化について

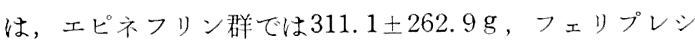
ン群では334.9土274.2 g で両群間に統計学的有意差は認
められなかった。

術中の SBP と出血量との関係をみると, 執刀開始よ り手術終了までの SBP の平均が $100 \mathrm{mmHg}$ 以下の群 の出血量は242.4土229.5 g, 101 120 mmHg の群の出 
血量は336.3土262.1 g , $121 \mathrm{mmHg}$ 以上の群は390.6土 $300.0 \mathrm{~g}$ であった. SBP $100 \mathrm{mmHg}$ 以下の群の出血量が 最も少なく，他の 2 群との間に統計学的有意差が認めら れた (図 4).

次に, 今回の症例の出血量に対する, 年战命, 体重, 手 術時間, SBPについて相閔関俰を検討した結果, 出血量 と年路では $\mathrm{R}=-0.0424$ と相関関係は認められなかっ たが，出血量と体重では $\mathrm{R}=0.2048$ と相関関係が認め

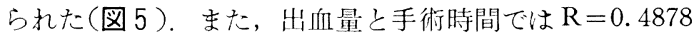
と相関関係が認められたが, 出血量と SBP では $\mathrm{R}=$ 0.0332 と相閔関係は認められなかった（図 6).

\section{考察}

上罘洞根治手術は歯性上顎洞炎や術後性上顎霆胞など を対象とした手術であり ${ }^{3,4)}$ ，当施設に拈壮る年間手術 例の5ち約30\%を占める比較的頻度の高い手術である。 当施設における上䫇洞根治手術の平均出向量は $370.4 \mathrm{~g}$ で，これは成人循環血液量のほぼ10\%に相当する量であ る。小川ら によよば，循環血液量の $20 \%$ に急速に失わ れるとショック症状が現われ，50\%以上が失われると不 可逆的ショックに移行すると報告している.

今回検索した 200 例のらち術中または術後に輸血を行 った症例は，術中約 1 時間に750〜 $1,350 \mathrm{~g}$ の出血をきた した 4 症例であるが，その他の症例も含めて出血による 重篤な不快症状は認められなかった。

手術時の出血量に影響を及沋因子としては，年畧， 体重, 出血性素因の有無などの患者側の因子，診断名， 手術時間などの術者側の因子と麻酔法，術中の血压変動 などの麻酔医側の因子があげられる。

今回対象となった患者の術前評価は，全例 ASA 分類 $1 \sim 2$ 度であり，術前の出血・㠜固系検查でも異常所見 は諗められなかったことから，出血性素因を除く他の因 子について検討を行った。

\section{1. 患者の年齢・体重}

加桷に伴ら血管性状の変化，体重による循環血液量の 違いなどが出血量に影響することも考えられたが，今回 の娭索では，年秢に䦥しては各年代の出血量に統計学的 有意差は認められず，出血量之の相閔関係も認められな かった。また体重に関して河野(6) plasma volume の增 加に伴い出血量の增加をみたとしており，本研究では21 $\sim 40 \mathrm{~kg}, 41 \sim 60 \mathrm{~kg}, 61 \mathrm{~kg}$ 以上の各群の出血量の間に統 計学的有意差は認められなかったが，体重と出血量との 開に相阙阙係が涊められた。

\section{2. 手術時間}

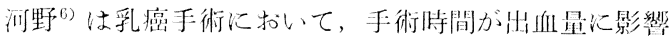
寸る因子であることを確㤎している。本研究では手術時 開が60分以下の症例は76例方り，出血星の平均は 206.6 gで，61〜120分の群と121分以上の群との間に統計学的
有意差が認められた。手術時間が $61 〜 120$ 分の症例は112 例々最も多く, 出血量の平均は $376.4 \mathrm{~g}$ で, 他の 2 群と の間に統計学的有意差が認められた。手術時間が 121 分 以上の症例は12例あり, 出血量の平均は $662.5 \mathrm{~g}$ と60分 以下の症例に比較し約 3 倍の出血量であった。なお，手 術時間と出血量との間には相関関係が認められた。

これらのことから，手術時間が出血量に大きな影響を 及ぼしてることが示唆された。

\section{3. 診断名}

幽性上顎洞炎群は術後性上顎嗺胞群より出血量が多 く, 統計学的有意差が認められた。

この要因としては前項で述べた手術時間と出血量の関 係があげられる。すなわち, 術後性上顎䚈胞群では手術 時間の平均が72.4分であるのに対し，歯性上顎洞炎群で は83. 7 分と10分以上の延長が認められる。.さらに，上䫕 洞根治手術に随伴した上㴿洞接閉鎖手術が歯性上顎洞炎 群では83例中26例に, 術後性上顎垔胞群では 117 例中18 例に施行されて敃り, 診断名による出血量の統計学的有 意差は認められたものの, 詳しくは手術術式の内容が手 術所要時間の延長, さらに出血量へ関与するものと考兄 なければならない

また，炎症性疾患と麗胞性疾患という患部の組織学的 造い, 各症例における炎症の程度や手術における術者の 技量の格差などにも影響を受けていると思われる。

\section{4. 麻酔法}

GOF, GOE, NLA の各群の出血量に統計学的有意差 は認められなかった。

しかし，局所止血の目的で使用される血管収縮薬添加 局所淋酔液が， GOF 群では全て 0.03 I.U.フェリプレ シン添加 $3 \%$ リロカイン, GOE 群および NLA 群で は, 注ぽ70\%が1/20万エピネフリン添加 $0.5 \%$ リドカイ ンであり，その使用法も切開前の 1 回に限る口腚粘膜へ の没潤投与であり，血管収猚薬を併用したほうが約 $20 \%$ の出血量の減少はみられるものの, 統計学的有意差はな いことから投与量, 投与方法なども含めて今後検討して いかなければならない点と考光る。

なお，GOF 麻酔下でのエピネフリンの使用について， 田辺ら゙は，2.5\%にェピネフリン催起性不整脈の発生 を認めて挆り，当科ではとの作用を避けている。

\section{5. 術中の SBP}

出血量は単位時間の単.位血管内の血流量に影響され ${ }^{8)}$, 収繀期血圧は出血量を左右する因子の一つであるとされ ている ${ }^{9,10)}$.

$\mathrm{SBP}$ の平均が $100 \mathrm{mmHg}$ 以下の群の出血量が最も少 なく, SBP 101 120 mmHg, $121 \mathrm{mmHg}$ 以上の各群に 対し統計学的有意差が認められた。このことから, 術中 の平均収縮期血生を $100 \mathrm{mmHg}$ 以下に保つことは，出 血量の減少につながると考えられる。

術中患者管理を担ら森酷科医にとって，外科手術時の 
出血量は重大な関心事項の一つである。今回得られた結 果から，術中出血量を減少させる因子として，術者は手 術時間の短樎に努めること，麻酔科医は術者に最適の術 野を提供すること，さらに低血圧麻酔を含めた麻酔法の 再検討が必要と考えられた。

\section{ま と め}

今回われわれは，昭和 54 年 2 月から昭和 62 年 5 月まで の期間に，歯性上顎洞炎および術後性上頡楚胞と診断さ れ, 日本齿科大学新潟齿学部附属病院中央手術室にて上 顎洞根治手術を受けた 200 例について，出血量と年朎・ 体重・手術時間・診断名・麻酔法・術中の血圧などの関 係を検討した。

対象の年齢と出血量との間には相関関係は認められな かったが，体重と出血量との間には相関関係が認められ た.

手術時間が長くなるほど出血量が増加する傾向にあ り, 統計学的有意差がみられ, 両者に相関関係が認めら れた。

術後性上顎整胞に比べ歯性上顎洞炎では出血量が多 く, 統計学的有意差が認められた。

麻酔法の種類, 血管収縮薬の種類, 血管収縮薬使用の 有無については統計学的有意差は認められなかった。

$\mathrm{SBP}$ の平均が $100 \mathrm{mmHg}$ 以下の群の出血量が最も少 なく, SBP 101 120 mmHg, $121 \mathrm{mmHg}$ 以上の各群に 対し統計学的有意差が認められた。

\section{引用 文 献}

1)斉藤志朗，滰口整：口腔外科に拈ける手術時 の出血量について。 日外誌 6: 123-124 1960.

2) 古本克鲘：各種口腔外科手術時の出血量につい て。日外誌 2: 37-40 1956.

3) 中村平蔵監修：最新口腔外科学，第 1 版，医獭 薬出版, 東京, 1971，543-561頁。

4) Gustav O. Kruger 編（河野甪雄訳）：Kruger 口腔外科学, 第 1 版, 医碀薬出版, 東京, 1973, 337-355面。

5）小川龍：麻瘦科医からみたショック治療の夷 際，第 1 版，真與交易医豐，東京，1983，1621 頁.

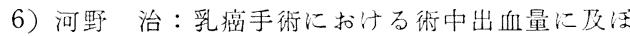
方諸因子の検討(その 1)一身体的，生理的扮よ び外的因子について一暦酔 26：78-89 1977.

7）田辺潔，金子譫，他：断科口腔外科の全身 麻酔に扣ける不整脈一特にェピネフリン催起性 不整脈について一日萪麻誌 9:468-473 1981.

8）河野治：乳瘦手術に扮计る術中出血量に及添 寸諸因子の検討(その 2 ) 一低血圧麻酔法と術中 出血量について一。麻酔 26：174-182 1977.

9）金子僙，大筧根洋，他：口腔外科手術に拈忛 る低血圧麻酔の臨床経験。日附麻誌 4：51-58 1971.

10）松岡秀樹, 斉藤等, 他：低血圧麻酔による頭 頚部手術。耳鼻咽喉科会誌 44：35-40 1972. 